\title{
TRANSFORMATION OF RURAL DEVELOPMENT ADMINISTRATOR'S FUNCTIONS
}

\author{
Lina Marcinkevičiūtè \\ Assoc. Prof. Vytautas Magnus University, Universiteto 10, Akademija, \\ E-mail lina.marcinkeviciute@vdu.lt
}

Received 0304 2019; Accepted 30052019

Municipalities and elderships, including rural ones, are the closest to the needs of each member of the society. Yet these organizations are currently facing great challenges. The article analyses the significance of the transformation of rural development administrators' functions and issues related to their activities in the changing environment. To identify the most significant knowledge and skills that are required of a rural development specialist. The main "existing" activity functions were identified, and potential activity functions related to strategic and potential documents of the EU and Lithuanian rural development were proposed. Based on the analysis of scientific sources and empirical research, the article discusses the content of competences, the conditions for transformation and the impact on both the teaching process and the working environment.

Key words: rural development administrators, functions, rural development policy and management.

JEL Codes: R58, Z18.

\section{Introduction}

Today's working environment demands one to have highly developed skills in order to use information flows, the latest technologies, speak several foreign languages, etc. The acquired professional experience is not static and is not accumulated permanently; therefore, education (especially the content of teaching) cannot remain unchanged. The education system must also react to the changes of the society, economics and the process of education itself. Knowledge and skills of the employees of municipality and elders have now become the main advantage (Osborne, 2015). Advantage is determined by exceptional competences of employees at all levels; therefore, it is worthwhile to accumulate them if there is a need to establish the interrelation of the employees. The requirements for the acquisition of professional competence in both business and public sector (municipalities and elders, etc.) have changed in the recent decades. The change of competencies is especially relevant to organizations that operate in the fastchanging working environment.

Copyright (C) 2019 The Authors. Published by Vytautas Magnus University, Lithuanian Institute of Agrarian Economics. This is an open-access article distributed under the terms of the Creative Commons Attribution-NonCommercial 4.0 (CC BY-NC 4.0) license, which permits unrestricted use, distribution, and reproduction in any medium, provided the original author and source are credited. The material cannot be used for commercial purposes. 
These organizations are faced with new social development needs of the society that have emerged from both global and local factors (Subrahmanyam; Ravichandran, 2013). Therefore, the competence of each employee, as well as the ability to transform the information possessed to individualised solutions, and to identify opportunities in new situations and help others to make use of them are important.

Public administrations of agriculture and rural development are highly bureaucratic and cover a wide range of regulatory and administrative functions. These functions are carried out by strictly sector-based administrations of agriculture and rural development. The functions include the specifics related to both agriculture and rural development. Special competencies are required here as well. The object of the research: the functions of a rural development specialist. The aim of the research: to investigate the changes of functions of rural development administrator and provide practical recommendations.

Notably, the changing and increasing needs of modern society encourage continuous learning and acquisition of new competences. A question is often raised as to which subjects, and to what extent, help one to develop professional competencies, especially their practical aspects. Identifying the latter would make it possible to improve the learning process and the links between the sharing of theoretical knowledge and the development of practical skills. This would help to encourage students or prospective students to examine the practical competences they already have and choose study programmes rationally.

\section{Theoretical analysis}

It can be observed that, as a result of changes in the environment, specialists that are newly trained in the higher education system have to not only understand national and business systems, their functioning and regulation mechanisms, but also initiate processes making use of the new opportunities. Decisions made at the workplace have a significant impact on the performance results and further development of the municipality and elderships, while the society is constantly increasing the requirements for study programmes, staff professionalism, responsibility, loyalty, etc (Tennyson, 2011; Vanthillo; Verhetsel, 2012).

Rural development is a relatively new field of social, political and economic life in Lithuania. Over the recent years, the peculiarities and needs of rural development specialists in public and private sectors have been rapidly changing, as skilled professionals are required to initiate and manage rural development processes. The need for rural development specialists is related to a rapidly developing rural development policy in the EU and Lithuania: agricultural policy is increasingly transformed into rural development policy (Factsheet on 2014-2020 Rural Development..., 2013). Therefore, specialists are needed who would initiate rural changes themselves: by developing rural businesses, working in companies, elderships, communities, or non-governmental organizations in various rural areas, 
etc. Recently, the need has emerged to reduce employment in agriculture and increase it in the fields that are based on local resources, such as rural tourism, business, etc. Today's rural areas are facing a period of population decline; therefore, employees who have knowledge and skills in rural and regional development policies are needed in order to ensure the effectiveness and efficiency of strategic management in these areas.

More attention should be paid to economic and social changes in rural areas in order to ensure the effectiveness of the administrative system and higher quality of life for the rural population, also to strengthen partnerships and community spirit. In order to reduce the risk of poverty in rural areas and increase employment possibilities, knowledge about rural development policy, and strategic management solutions that can initiate long-term strategies (cultural, social and economic) of rural areas are needed (Description of Rural Development Administration Programme, 2016). Since 2012, a model of competencies has been introduced in Lithuania for the development and implementation of which is the responsibility of the Department of Public Service. In the UK, Holland, Belgium and Sweden, unlike Lithuania, the competence model has been in use for more than a decade (Table 1).

Table1. Comparison of competency models used in European countries (made by Department of Public Service, 2015)

\begin{tabular}{|l|l|l|l|}
\hline \multicolumn{1}{|c|}{$\begin{array}{c}\text { UK } \\
\text { (decentralized model) }\end{array}$} & $\begin{array}{c}\text { Holland } \\
\text { (centralized } \\
\text { model) }\end{array}$ & $\begin{array}{c}\text { Belgium } \\
\text { (centralized model) }\end{array}$ & $\begin{array}{c}\text { Sweden } \\
\text { (decentralized } \\
\text { model) }\end{array}$ \\
\hline $\begin{array}{l}\text { General Model of } \\
\text { Competences of Professional } \\
\text { Skills in Public Service }\end{array}$ & $\begin{array}{l}\text { General model of } \\
\text { public service } \\
\text { competencies }\end{array}$ & $\begin{array}{l}\text { Competency Model } \\
5+1\end{array}$ & $\begin{array}{l}\text { No centralized } \\
\text { model }\end{array}$ \\
\hline
\end{tabular}

In order to provide justification for the demand for rural development specialists and their competencies, a professional field survey was carried out in 2016-2017, i.e. a questionnaire survey of potential employers of rural development administration graduates at Aleksandras Stulginskis University (now VMU Agricultural Academy). More than half of the employers who were interviewed $(52,6$ percent) believe that in the next 5 years their organizations will need rural development specialists with the following knowledge: rural business management, public policy, rural development administration, marketing management, place marketing, strategic planning, information technologies and computer literacy, public project management, decision management, and law, and also with the skills of entrepreneurship, consulting, public project management, business plan preparation, organizational and creative abilities (Description of Rural Development Administration Programme, 2016). According to the members of the Lithuanian Association of Municipal Elders, in order to satisfy rural development needs of the country, voluntary work and enthusiasm of the heads and members of rural community organizations and local activity groups are not 
enough. Professional assistance as well as coordination of the efforts and actions of rural development participants are needed (Description of Rural Development Administration Programme, 2016).

Analysing the ruling of the Ministry of the Interior of the Republic of Lithuania regarding the employment of rural development specialists of municipal administrations or the retraining of currently available agricultural specialists, the following proposals of the ministry can be observed: to strengthen the economic and expert foundations of the regions in order to make them strong centres of growth and attractive centres for business and living in the long-term by developing an infrastructure that ensures high quality of life and building attractive regions in which local and foreign business companies would invest and which would offer a competent workforce and a comprehensive modern infrastructure with competent authorities (Decision of the Ministry of the Interior of the Republic of Lithuania, 2017).

Significantly, the EU pays a lot of attention to rural development. Rural development measures are planned in the National Rural Development Programme 2014-2020, Long-Term Development Strategy and the following EU strategic documents: Europe 2020 Strategy, Treaty of Lisbon, Communication on Common Agricultural Policy. The LEADER method, which is intended for the promotion of local initiatives in rural communities, is applied in Lithuania. This large financial support can be effectively absorbed only with professional assistance provided by rural development specialists to agricultural companies, the Advisory Service, rural self-government institutions, agricultural product processing industry, commercial structures, and agricultural entities.

According to research data, the need for rural development specialists has especially increased after Lithuania joined the EU. Having evaluated the activity operations that are emphasized in national and international documents (Europe 2020: A Strategy for Smart..,2010; Operational Programme for the EU..., 2013), it is imperative to link the functions of rural development administrator to the following: the impact of individual entrepreneurship on economic, social, and psychological rural development processes; the changing structure of agricultural and other rural businesses, modernization of farms (Description of Rural Development Administration Programme, 2016).

In order to control these processes, employees are needed who are acquainted with modern management principles and are able to adapt these principles to specific conditions. It is hardly possible to carry out qualitative and quantitative structural changes under modern conditions with inadequate internal capacities of rural residents. Thus, the following are needed: managers and project administrators of rural development institutions capable of strategically and innovatively managing local resources and solving economic and social problems; there is a great need for reorganization of rural economic activities by reducing employment in agriculture and increasing employment in local resource-based businesses, particularly in the production of high-quality regional products and 
recreational services; development and reorganization of rural self-government institutions, non-governmental organizations and other public entities (Description of Rural Development Administration Programme, 2016).

The demand for the activities and functions of a rural development administrator can be identified in the analysis of rural development programming and strategic documents (Europe 2020: A Strategy for Smart, Sustainable and Inclusive Growth; Operational Programme for the European Union Funds' Investments in 2014 - 2020; Lithuanian Rural Development Programme for 2014 2020 and etc. Information about the planned rural development activity fields, including the description of priorities and functions of a rural development administrator, is provided in Table 2.

Table 2. Functions of rural development administrator based on strategic and programming documents of rural development

\begin{tabular}{|c|c|c|}
\hline Priority & Field of activity & $\begin{array}{l}\text { Rural development administrator's } \\
\text { functions }\end{array}$ \\
\hline \multicolumn{3}{|c|}{ Document: Europe 2020: A Strategy for Smart, Sustainable and Inclusive Growth } \\
\hline $\begin{array}{l}\text { Smart growth: developing } \\
\text { an economy based on } \\
\text { knowledge and innovation }\end{array}$ & Youth on the move & $\begin{array}{l}\text { Promotion of entrepreneurship and } \\
\text { integration of young people into the labour } \\
\text { market }\end{array}$ \\
\hline $\begin{array}{l}\text { Sustainable growth: } \\
\text { promoting a more } \\
\text { resource efficient, greener } \\
\text { and more competitive } \\
\text { economy }\end{array}$ & $\begin{array}{l}\text { An industrial policy } \\
\text { for the globalization } \\
\text { era }\end{array}$ & $\begin{array}{l}\text { Promotion of favourable business } \\
\text { environment and close partnership among } \\
\text { non-governmental organizations, private } \\
\text { (business) and public sectors }\end{array}$ \\
\hline $\begin{array}{l}\text { Inclusive growth: } \\
\text { fostering a high- } \\
\text { employment economy } \\
\text { which ensures economic, } \\
\text { social and territorial } \\
\text { cohesion }\end{array}$ & $\begin{array}{l}\text { An agenda for new } \\
\text { skills and jobs }\end{array}$ & $\begin{array}{l}\text { Promotion of social dialogue and } \\
\text { partnership between the education sector } \\
\text { and the labour sector by including social } \\
\text { partners in the planning of study } \\
\text { programmes }\end{array}$ \\
\hline $\begin{array}{l}\text { Development of safe and } \\
\text { clean environment }\end{array}$ & $\begin{array}{l}\text { Support of } \\
\text { environmental } \\
\text { protection }\end{array}$ & $\begin{array}{l}\text { Complex landscaping of heritage objects, } \\
\text { their management and adaptation for } \\
\text { cultural, educational and social needs by } \\
\text { utilising their social, natural and economic } \\
\text { potential in an innovative manner }\end{array}$ \\
\hline \multicolumn{3}{|c|}{ Document: Operational Programme for the European Union Funds' Investments in $2014-2020$} \\
\hline $\begin{array}{l}\text { Environmental protection, } \\
\text { sustainable use of natural } \\
\text { resources and adaptation } \\
\text { to climate change }\end{array}$ & $\begin{array}{l}\text { Protection, promotion } \\
\text { and development of } \\
\text { cultural and natural } \\
\text { heritage }\end{array}$ & $\begin{array}{l}\text { Improvement of the relevance, attendance } \\
\text { and visibility of cultural and natural } \\
\text { heritage, including public awareness of the } \\
\text { surrounding environment; landscaping of } \\
\text { protected territories and adaptation of } \\
\text { these territories for visitors. }\end{array}$ \\
\hline $\begin{array}{l}\text { Promotion of high-quality } \\
\text { employment and } \\
\text { participation in the labour } \\
\text { market }\end{array}$ & $\begin{array}{l}\text { Growth of } \\
\text { employment-boosting } \\
\text { economy through the } \\
\text { development of }\end{array}$ & $\begin{array}{l}\text { Increasing diversity of economic activities } \\
\text { and improving conditions for attracting } \\
\text { investments in order to create new jobs in } \\
\text { target territories }\end{array}$ \\
\hline
\end{tabular}




\begin{tabular}{|l|l|l|}
\hline & internal potential & \\
\hline \multicolumn{2}{|c|}{ Document: Lithuanian Rural Development Programme for 2014-2020 } \\
\hline $\begin{array}{l}\text { Enhance viability of farms } \\
\text { and competitiveness of all } \\
\text { types of farming in all } \\
\text { regions, promote } \\
\text { innovative farm } \\
\text { technologies and } \\
\text { sustainable management }\end{array}$ & $\begin{array}{l}\text { Improvement of } \\
\text { economic } \\
\text { performance results } \\
\text { and provision of better } \\
\text { conditions for farm } \\
\text { restructuring and } \\
\text { modernization in } \\
\text { order to promote } \\
\text { participation in the } \\
\text { market and } \\
\text { orientation, also } \\
\text { diversification of } \\
\text { agriculture }\end{array}$ & $\begin{array}{l}\text { Improvement of the living environment in } \\
\text { residential districts by creating or } \\
\text { infrastructure, managing the environment, } \\
\text { investing in the green infrastructure and } \\
\text { accessibility of these territories }\end{array}$ \\
\hline $\begin{array}{l}\text { Promotion of social } \\
\text { inclusion, poverty } \\
\text { reduction and economic } \\
\text { development in rural areas }\end{array}$ & $\begin{array}{l}\text { Promotion of local } \\
\text { development in rural } \\
\text { areas }\end{array}$ & $\begin{array}{l}\text { Promotion and development of foreign and } \\
\text { local investments in rural areas. } \\
\text { Conversion of abandoned and } \\
\text { ineffectively used buildings, other } \\
\text { infrastructure and territories; enhancement } \\
\text { of their functionality }\end{array}$ \\
\hline
\end{tabular}

Study data, in Lithuania there is a tendency to follow methodologically different concepts, models of different management schools and theories, trying to apply several systems at once and as a result the management effectiveness remains rather low. Employees do not have enough time to understand one concept but already have to reorient themselves to the next one. Often there are attempts to mechanically transfer the western organisation forms and management methods (instead of adapting them) without considering the real situation of the country. This leads to social conflict, and work results are inadequate.

To sum up, in today's global world, Lithuania and other countries are facing new and complex challenges which cannot be solved using a single sectoral approach. A rural administrator who represents only the public sector will not be able to meet the increasing needs of a changing society, because the narrow field of activity limits the capacity of public institutions to satisfy these needs. Enabling different sectors to work effectively to ensure social welfare in rural areas implies the need to analyze and apply different forms of activity in practice.

\section{Research Methods}

The research was carried out in three stages.

The first stage included the analysis of the descriptions of first and second cycle study programmes of Administration of Rural Development (2016) taught at the Faculty of Economics and Management of Aleksandras Stulginskis University in order to identify the most significant knowledge and skills that are required of a 
rural development specialist (using the knowledge and skills described in the study programs that students should have). During the analysis, a structured interview questionnaire was prepared for experts, which was based on statements describing knowledge and different skills (special, social, personal, research).

In the second stage, under structured interview questionnaire (interview questions were formulated in the 1st and 2nd study programs, the first stage), using a modified Stapel scale, experts had to evaluate potential knowledge and skills of rural development specialist by their significance and potential benefit (1 completely insignificant, 5 - very important) (Šlekys, 2018). Experts (residing and working in various elderships) were selected for the research in accordance with the following selection criteria: 1) position; 2) work experience in the respective field (at least 2 years). The research included elders, chairpersons of communities, directors of the Multi-Functional Centre, and specialists of the Department of Agriculture (total 35 experts).

In the third stage, after analysing the staff regulations for the specialists of the municipal administrations in the Department of Agriculture and were interviewed Rural development specialists of Lithuanian municipalities and elderships (questionnaires were sent by e-mail to 60 Lithuanian municipalities and 546 elderships, data was received from 18 municipalities and 157 elderships, with a total of 185 questionnaires), the main "existing" activity functions were identified, and potential activity functions related to strategic and potential documents of the EU and Lithuanian rural development were proposed.

\section{Research Results}

Under structured interview questionnaire (which was prepared in the first stage), table 3 shows the essential results.

Table 3. Expert opinions about knowledge and skills in the work of a Rural Development specialist (maximum 5 points)

\begin{tabular}{|l|c|c|}
\hline The knowledge and skills & $\begin{array}{c}\text { The knowledge and skills of the } \\
1 \text { study programme, points }\end{array}$ & $\begin{array}{c}\text { The knowledge and skills of } \\
\text { the 2 study programme, points }\end{array}$ \\
\hline $\begin{array}{l}\text { Knowledge and its } \\
\text { application }\end{array}$ & 3,6 & 4,7 \\
\hline Special skills & 4,4 & 4,1 \\
\hline Personal skills & 3,1 & 3,5 \\
\hline Social skills & 4,0 & 3,9 \\
\hline $\begin{array}{l}\text { Skills related to the } \\
\text { implementation of research }\end{array}$ & 3,8 & 3,3 \\
\hline
\end{tabular}

Expert opinions regarding the importance of knowledge and skills in the work of a rural development specialist are distributed: when assessing the knowledge and skills of the first-cycle study programme, experts emphasized special skills of the rural development administrator (experts gave 4,4 points), which in their 
opinion could include the ability to develop and implement rural development programmes and projects by allocating and managing the resources of NGOs and private and public sectors as well as pursuing effective use of these resources. In the experts' opinion, personal skills (experts gave 3,1 points) were less significant when assessing opportunities of partnership activities, because they were associated with the personal characteristics of each employee, which may not always be used for a common purpose.

When assessing the knowledge and skills of the second-cycle study programme, experts highlighted knowledge and its application as very important to a specialist (experts gave 4,7 points), as the application of knowledge helps to create new opportunities for action. In the opinion of the experts, skills related to the implementation of research are less important (experts gave 3,3 points), because it is rather difficult to carry out research (questionnaires, interviews, etc.) in rural areas due to the passivity of locals when initiating changes. After the experts' opinions were stopped, they were compared with interviewed Rural development specialists of Lithuanian municipalities and elderships (third stage).

The highest number of agricultural specialists working in municipalities and elderships was in the age category of 51-60 years (75\% respondents) with 11-20 years (68\% respondents) of professional experience. The largest number $(85 \%)$ of respondents had acquired engineering and agronomy specialities (only $15 \%$ employees improved their qualifications within 5 years).

Despite the fact that the majority of respondents have higher education and long professional experience, the following conclusion can be made: the knowledge they acquired 20-30 years ago is only episodically applied in the activities (such as economic and business development, renewal of services in rural areas, promotion of cooperation and sociality, etc.) in the existing programming and strategic documents (Operational Programme for the European Union Funds' Investments in 2014 - 2020; Europe 2020: A Strategy for Smart, Sustainable and Inclusive Growth and etc.), because they lack special skills, such as consulting rural development specialists, representing their interests, and planning and implementing strategic activities as their specialities were engineering or agronomy. The aforementioned skills are developed during the following subjects of the first and second cycle study programmes of Administration of Rural Development: Business Strategic Management, Rural Development Management, Development of Regional Competitiveness, etc.

In literature (Decision of the Ministry..., 2017) the concept of "work function" is defined as working in a certain profession, speciality, qualification or a certain specific position. The lack of a detailed regulation on the agreed-upon work in written documents may result in a sort of uncertainty when performing the employment contract and a lack of clarity when solving disputes arising from the employment contract. This means that, when discussing the description of employee functions, it is recommended to specify the employee's duties, the main purpose for which the organization needs him, in the employment contract. 
It is worth pointing out that appropriate job descriptions are an important element in the planning of the demand for jobs. If inconsistencies are identified between the functions specified in the job description and the actual activities performed by the employee, it is necessary to review the situation and evaluate and make corrections: either in the job description or in the activities. Individual job descriptions that define the functions of separate employees in detail play a rather significant role in organisations. After analysing the functions of municipality and eldership employees, it was determined that the activities that are the most closely related to those performed by the rural development administrator could be the activities of the agricultural specialist. It has been noted that in certain municipalities (in Ukmergè, Molètai) or elderships (Dubingiai, Luokesa, Suginčiai Ašminta, Balbieriškis, Naujoji Ūta), the position of agricultural specialist has been "renamed" to the position of rural development administrator or specialist for rural development, which retains the functions identified in 2008-2010, even though the methodology of the job demand assessment by the Civil Service Department states that the analysis of jobs should be closely connected to the factors and characteristics of organisational development: the organisation's structure, shortterm and long-term goals, functions, organisational culture, and the quality and style of the management.

The positions documented in the job descriptions should be determined and developed based on these factors: specifying the job's purpose, accountabilities, qualification requirements, career path, substitutability possibilities and other related information (Civil Service Department, 2014; State Service Department, 2017). Table 4 provides the current functions of an agricultural specialist and the functions of a rural development administrator that are needed today.

Table 4. Analysis of current functions of agricultural specialists and required functions of rural development administrators (made by the authors based on (Bella, Grant, Kindornay, Tissot, 2013; Matonienè, 2015; Mulgan, 2016)

\begin{tabular}{|l|l|}
\hline $\begin{array}{c}\text { Current functions of agricultural } \\
\text { specialist }\end{array}$ & \multicolumn{1}{|c|}{$\begin{array}{c}\text { Required functions of rural development } \\
\text { administrator }\end{array}$} \\
\hline $\begin{array}{l}\text { Management of agricultural } \\
\text { production quotas, registration of } \\
\text { holdings and farms; registration and } \\
\text { maintenance of tractors, autonomous } \\
\text { and agricultural vehicles and their } \\
\text { trailers }\end{array}$ & $\begin{array}{l}\text { Increasing competitiveness of business, tourism, and } \\
\text { agriculture (creating favourable environment for } \\
\text { economic growth by improving the conditions for } \\
\text { initiating business and the quality of the living } \\
\text { environment, supporting the activities of the society, } \\
\text { and encouraging innovations in agriculture) }\end{array}$ \\
\hline $\begin{array}{l}\text { Organizing implementation of } \\
\text { agricultural environmental protection } \\
\text { measures, promoting ecological } \\
\text { farming and sustainable agriculture }\end{array}$ & $\begin{array}{l}\text { Execution of industrial policy adapted to the } \\
\text { globalization era, promoting creation of a business- } \\
\text { friendly environment and close partnership between } \\
\text { NGOs and public and private sectors }\end{array}$ \\
\hline $\begin{array}{l}\text { Participation in the preparation and } \\
\text { implementation of long-term and } \\
\text { short-term rural infrastructure }\end{array}$ & $\begin{array}{l}\text { Implementation of measures from strategic and } \\
\text { programme-based rural development and programme } \\
\text { documents (business creation, promotion of youth }\end{array}$ \\
\hline
\end{tabular}




\begin{tabular}{|l|l|}
\hline $\begin{array}{l}\text { programmes approved by the } \\
\text { municipal council }\end{array}$ & $\begin{array}{l}\text { initiatives, provision of social services, etc.) in rural } \\
\text { area }\end{array}$ \\
\hline $\begin{array}{l}\text { Preparation of reports and } \\
\text { information on behalf of } \\
\text { municipality to the Ministry of } \\
\text { Agriculture and the Statistics } \\
\begin{array}{l}\text { Department under the Government } \\
\text { of the Republic of Lithuania }\end{array}\end{array}$ & $\begin{array}{l}\text { Periodical provision of reports or information on } \\
\text { implementation of rural development in the rural area to } \\
\text { the interested parties (National Paying Agency, } \\
\text { Ministry of Agriculture, Statistics Department, etc.) }\end{array}$ \\
\hline $\begin{array}{l}\text { Consulting agriculture subjects on } \\
\text { the possibility of receiving funding } \\
\text { from state programmes }\end{array}$ & $\begin{array}{l}\text { Promoting best practices, conducting training, and } \\
\text { consulting rural development actors on development of } \\
\text { innovative, sustainable, and inclusive activities }\end{array}$ \\
\hline $\begin{array}{l}\text { Cooperation with the regional } \\
\text { administration and agricultural self- } \\
\text { government institutions }\end{array}$ & $\begin{array}{l}\text { Initiating partnerships with rural development actors } \\
\text { (rural community, school, church, farmers etc.) in the } \\
\text { absorption of funding for national and EU-supported } \\
\text { rural development projects }\end{array}$ \\
\hline
\end{tabular}

In conclusion, it is evident that, as a result of the changes taking place in rural areas, such as development of business and infrastructure and the interaction between community organisations, agricultural specialists should possess knowledge related not only to agriculture but also culture and tourism management, rural development administration, and agricultural management.

\section{Conclusions}

Public administration institutions of agriculture and rural development are highly bureaucratized and encompass a large number of various regulatory and administrative functions which involve specifics related to both agriculture and rural areas; thus, the performance of the aforementioned functions requires special competencies.

The demand for rural development administrators experienced a sharp increase after Lithuania joined the EU. Taking into account the priorities emphasised in the national and international documents, today the functions of rural development administrator must be connected to: the impact of an individual's entrepreneurship on the economic, social, and psychological processes of rural development; the changing structure of agricultural and other rural businesses; the modernization of farms.

In certain municipalities and in the elderships, the position of agricultural specialist has been "renamed" to the position of rural development administrator or specialist for rural development, which retains the functions identified in 20082010, even though the methodology of the job demand assessment by the Civil Service Department states that the analysis of jobs should be closely connected to the factors and characteristics of organisational development: the organisation's structure, short-term and long-term goals, functions, organisational culture, and the quality and style of the management. 


\section{Management Theory and Studies for Rural Business and Infrastructure Development \\ eISSN 2345-0355. 2019. Vol. 41. No. 2: 237-248 \\ Article DOI: https://doi.org/10.15544/mts.2019.20}

\section{References}

Aleksandras Stulginskis University (now VMU Agricultural Academy). 2016. Description of Rural Development Administration Programme.

Bella, J. D., Grant, A., Kindornay, S., Tissot, S. (2013). The Private Sector and Development: Key Concepts.-http://www.nsi-ins.ca/wp-content/uploads/2013/09/The-PrivateSector-and-Development-Key-Concepts-FINAL-Policy-Brief.pdf [ 1503 2018]

Europos Komisija. 2010. Europa 2020: pažangaus, tvaraus ir integracinio augimo strategija (Europe 2020: A Strategy for Smart, Sustainable and Inclusive Growth).http://ukmin.Irv.lt/uploads/ ukmin/documents/files/Strategija\%202020\%20LT.pdf [2018 05 15].

Europe 2020: a European Strategy for Smart, Sustainable and Inclusive Growth. European Commission, Brussels. - http://ec.europa.eu/eu2020/pdf/COMPLET EN BARROSO 007 Europe 2020 - EN version.pdf. [10 02 2018].

Europos Sajungos 2014-2020 metu fondų investicijų veiksmų programa (Operational Programme for the European Union Funds' Investments in 2014-2020).http://www.esinvesticijos.lt/uploads/ documents/docs/160_61751e80960605f6c8c1a2545e5c1449.pdf [ 201805 15].

Factsheet on 2014-2020 Rural Development Programme for Lithuania. https://ec.europa.eu/agriculture/sites/agriculture/files/rural-development-20142020/countryfiles/lt/factsheet_en.pdf. [15 12 2018].

Lietuvos Respublikos Vidaus reikalų ministerijos sprendimas dèl savivaldybių administracijos kaimo plètros specialistų įdarbinimo ar šiuo metu esamų žemès ūkio specialistų perkvalifikavimo (Decision of the Ministry of the Interior of the Republic of Lithuania).2017.http://.fntt.lt/data/public/uploads/2016/10/2014_vrm_ataskaita.pdf [2018 12 20]

Lietuvos Respublikos Finansu Ministerija. 2016. Partnerystès principo taikymo, igyvendinant 2014-2020 metų Europos Sajungos fondų investicijų veiksmų programą, gairès.http://www.esinvesticijos.lt/lt/dokumentai/partnerystes-principo-taikymo-igyvendinant-20142020-metu-europos-sajungos-fondu-investiciju-veiksmu-programa-gaires [2018 0315 ].

Lietuvos Respublikos Žemès Ūkio Ministerija. 2015. Lietuvos kaimo plètros 2014-2020 metu programa (Lithuanian Rural Development Programme for 2014-2020).https://ec.europa.eu/agriculture/sites/agriculture/files/rural-development-2014-2020/countryfiles/lt/fulltext_lt.pdf [ 201805 15].

Matonienè, R. (2015). Sustainable regeneration in urban areas.http://urbact.eu/sites/default/files/04_sustreg-web.pdf [2018 0515 d] .

Mulgan, G. (2016). Collaboration and collective impact: how can funders, NGOs and Governments achieve more together.https://www.nesta.org.uk/sites/default/files/collaboration_and_collective_impact__geoff_mulgan.pdf [15 05 2018].

Pilietinès Visuomenès Institutas. (2015). Valdžios ir nevyriausybinių sektoriu bendradarbiavimo viešosios politikos sprendimų prièmimo procese stiprinimas.http://www.civitas.lt/wp-content/uploads/2015/08/VRM-tyrimo-ataskaita_final.pdf $\quad\left[\begin{array}{ll}2019 & 01\end{array}\right.$ 15].

Subrahmanyam, C.V.V., Ravichandran, K. (2013). The Role of Universities in Rural Development // IOSR Journal of Business and Management (IOSR-JBM). Vol. 8. Issue 5: 2327. - http://www.academia.edu/7373540/The_Role_of_Universities_in_Rural_Development [06 12 2018].

Šlekys, D. (2018). Specialisto kaimo plètrai vaidmuo siekiant horizontalios parnerystès. Magistro tezès. Akademija. - 55 p. 
Tennyson, R. (2011). International Business Leaders Forum: the Partnering toolbook.https://thepartneringinitiative.org/wp-content/uploads/2014/08/Partnering-Toolbook-en20113.pdf. [22 10 2017].

The 2016 Public Sector for the Future Summit: Designing Public Services for a Digital World. - https://www.accenture.com/_acnmedia/PDF-40/Accenture-Designing-PublicServiceDigital-World-2.pdf [09 12 2018].

Valstybės tarnybos departamentas.2015.Užsienio šalyse taikomu kompetencijų modelių bei pareigybių sisteminimo principų tyrimo ataskaita.https://vtd.Irv.lt/uploads/vtd/documents/files/VEIKLA/Vykdomi_projektai/Kompetencijos_ir_E PAK/Uzsienio\%20tyrimo\%20santrauka.pdf [2018 07 20].

Valstybės Tarnybos Departamentas. 2014. Pareigybių poreikio ịvertinimo metodika: II metodikos dalis: pareigybių poreikio ivertinimo modeliai.http://www.esparama.lt/documents/10157/490675/Pareigybiu_poreikio_ivertinimo_metodika.pdf /86957e61-fbe9-422b-82a4-c1d7ca06137b. [ 201802 16]. rengimo

Valstybės Tarnybos Departamentas. 2017. Valstybės tarnautojų pareigybių aprašymų http://portalas.vtd.lt/upload/Rekomendacijoms/Rekomendacijos\%20del\%20pareigybiu\%20apras ymo\%20rengimo_17-06-28.pdf. [2018 03 06].

Vanthillo, T., Verhetsel, A. (2012). Paradigm change in regional policy: towards smart specialisation? Lessons from Flanders (Belgium)//Belgeo Revue belge de géographie 1-2. http://belgeo.revues.org/7083. [12 12 2018].

\title{
KAIMO PLE்TROS ADMINISTRATORIAUS FUNKCIJŲ TRANSFORMACIJA
}

\author{
Lina Marcinkevičiūtè \\ Vytauto Didžiojo universitetas, Universiteto g. 10, Akademija, \\ El.pašto adresas lina.marcinkeviciute@vdu.lt
}

Gauta 201904 03; priimta 20190530

Seniūnijos, tarp jų ir kaimiškosios, yra arčiausiai kiekvieno visuomenès nario poreikių. Tačiau šios institucijos šiuo laikotarpiu patiria didelius iššūkius, nes turèdamos gana ribotą savarankiškumo laipsnị ir ribotos kompetencijos darbuotojus, turi atsakyti už paskirtas funkcijas bei tikslus, nors galètų atsakyti už daugiau funkcijų būdamos savarankiškesnès, nes yra arčiau žmonių ir labiau suvokia jų poreikius. Galima pastebėti, kad kintantys ir didejjantys šiuolaikinès visuomenès poreikiai skatina nuolatinį mokymąsi ir naujų kompetencijų ịgijimą. Dažnai kyla klausimas, kurie dalykai ir kokiu mastu ugdo profesinę kompetenciją, o ypač praktinius jos aspektus. Pastaruosius identifikavus, būtų galima tobulinti mokymosi procesą, gerinti teorinių žinių perteikimo ir praktinių igūdžių ugdymo ryšius. Šitai padètų skatinti studijuojančius ar ketinančius studijuoti asmenis analizuoti turimas praktines kompetencijas ir tikslingai pasirinkti mokymo programas. Straipsnyje analizuojama kaimo plètros administratoriaus funkcijų transformacijos svarba bei veiklos problemos kintančioje aplinkoje. Straipsnyje, remiantis mokslinès literatūros šaltinių analize ir empiriniais tyrimais, aptariamas kompetencijų turinys, nagrinejjamos transformacijos prielaidos ir poveikis tiek mokymo procesui, tiek darbo aplinkai.

Key words: rural development administrators, functions, rural development policy and management.

JEL Codes: R58, Z18. 